\title{
ADDER'S-MOUTH ORCHIDS IN SASKATCHEWAN
}

VERNON L. HARMS, The W.P. Fraser Herbarium, and Department of Biology, University of Saskatchewan, Saskatoon, Saskatchewan. S7N OW0

In a recent Blue Jay article, Bernard de Vries, while commenting on Donald Hooper's earlier account of finding White Adder's-mount [Malaxis monophyllos (L.) Swartz var. brachypoda (Gray) Morris \& Eames] along the Fir River Road in the Pasquia Hills, stated that this "... brought to mind a similar ... find in 1972 when ... (he had discovered this same orchid) in a small willow bog at Little Boggy Creek near Runneymede". ${ }^{6}{ }^{13}$ de Vries added that "this collection precedes the earliest reference given for this orchid in Saskatchewan by two years", citing as a reference for this statement the Syllogeus booklet on the rare plants of Saskatchewan. ${ }^{17}$ Actually the finding of White Adder's-mouth in the province predates this considerably, but there are understandable reasons for at least some possible confusion with regard to the historical story of adder's-mouth discoveries in Saskatchewan. Unfortunately contributing to this somewhat muddled state, were some early misidentifications and resulting erroneous reports (e.g. $7 \& 8,3 \& 4$ ), general provincial reports lacking locality citations (e.g. $10 \& 1$ ), sometimes incomplete literature referencing (e.g. 3, 17 \& 6 ), and the dispersion of voucher specimens among various, sometimes small or private herbaria.

The present paper has a two-fold objective. First, it is intended to correct potential misconceptions with regard to the history of adder's-mouth discoveries in Saskatchewan, giving credit to the earlier collectors in the province. Secondly, it is intended to summarize current knowledge of habitats and distributions in Saskat- chewan of adder's-mouth (Malaxis) species, our smallest, most delicate, least conspicuous, and perhaps rarest orchids.

The herbaria serving as repositories for the voucher specimens that document the locality records, are indicated below by the acronyms ascribed to them in the internationally accepted Index Herbariorum (plus several additional ones in quotes) as follows: CAN (National Museum of Natural Sciences, Ottawa), DAO (Department of Agriculture, Ottawa), FQH (Fort Qu'Appelle Herbarium, B. de Vries), "JHH" (John H. Hudson Herbarium, Saskatoon), "RCR" (R.C. Russell Herbarium, Canada Agriculture Research Station, Saskatchewan), SASK (The W.P. Fraser Herbarium, University of Saskatchewan, Saskatoon), and USAS (University of Regina Herbarium).

Our native adder's-mouth species are rather small green orchids, mostly less than $2 \mathrm{dm}$ (8") tall, arising from solid corms, with the leaves either solitary or several and then alternate, usually sub-basal. The flowers are yellowish- or whitish-green, small or relatively inconspicuous, $6 \mathrm{~mm}\left(1 / 4^{\prime \prime}\right)$ broad or less, born several to many in slender spike-like racemes. The unspurred lip-petals and other perianth parts are mostly less than $3 \mathrm{~mm}\left(1 / 8^{\prime \prime}\right)$ long (often only about one-half of these sizes). The two known Saskatchewan species - the White and Bog Adder's-mouth - plus the still unverified Green Adder's-mouth, can be distinguished from each other by means of the characters in the following identification key: 
1a. Leaves $2(-4)$ sub-basal but alternate, ovate-lanceolate to oblanceolate, only $1-3 \mathrm{~cm}$ long; tubers usually 2 in vertical tandem, the new tubers forming in axils of the sheathing leaves; flowers minute, less than $3 \mathrm{~mm}$ broad; lip-petal uppermost (inverted from that of typical orchid flowers), only $1.5 \mathrm{~mm}$ long, ovate with acute or somewhat acuminate apex, dark-green-nerved; sepals 2-2.5 $\mathrm{mm}$ long, distinctly longer than the lip and lateral petals; scapes and spike-like racemes very slender and lax, the flowering racemes less than 5 $\mathrm{mm}$ thick - Malaxis paludosa (Bog Adder's-mouth)

1b. Leaf solitary, broad-elliptic to oblong, 3-6 (-8) cm long; flowers larger, 3-6 $\mathrm{mm}$ broad; lip-petal lowermost, $2-4 \mathrm{~mm}$ long, more or less cordate with basal auricles, lacking dark-green veins; sepals and petals subequal in length, 2-3 $\mathrm{mm}$ long; flowering racemes over $5 \mathrm{~mm}$ thick -(2)

2a. Leaf attached near base of scape (flowering stem); lip-petal triangular, abruptly narrowed to a long-tapering point, drooping or reflexed; flowerstalks shorter than the flowers, only 1-2 mm long; flowering racemes less than $1 \mathrm{~cm}$ thick - Malaxis monophyllos var. brachypoda (White Adder's-mouth).

2b. Leaf inserted near middle of scape; lip-petal deeply cleft nearly halfway to base with a small tooth in the notch, somewhat ascending or upturned; flower-stalks longer than the flowers, to $8 \mathrm{~mm}$ long; flowering racemes over $1 \mathrm{~cm}$ thick - Malaxis unifolia (Green Adder's-mouth)

The first Saskatchewan collection of White Adder's-mouth (Malaxis monophyllos var. brachypoda) appears to have been by Dr. W.P. Fraser, 6 July 1934, from Lake Waskesiu (in SASK \& RCR). Unfortunately he originally misidentified this collection as Green Adder's-mouth (Malaxis unifolia Michx.) and the Lake Waskesiu locality reported under the latter name in Editions 1 and 2 of the Fraser and Russell Saskatchewan plant lists ${ }^{8},{ }^{9}$. The name was corrected to $M$. brachypoda (Gray) Fern. in the Edition 3 revision, but this edition omitted all locality citations ${ }^{10}$. August Breitung, listed this taxon as M. monophyllos var. brachypoda, (as it is usually treated today), and reported it only from Lake Waskesiu ${ }^{4}$. Rather surprisingly, a decade later, Voivin still questioned the Saskatchewan occurrence of this species, apparently considering that the earlier reports by
Fraser and Russell and Breitung needed verification. ${ }^{1} 104$ Boivin's own annotation label dated the same year (1967), however, appears on the SASK specimen of W.P. Fraser's Lake Waskesiu collection.

The second Saskatchewan locality to be recorded for White Adder'smouth was from 5-7 miles south of Macdowall (about 25 miles southwest of Prince Albert), where it apparently was first collected 12 August 1946 by Dr. R.C. Russell, Canada Agriculture Research Station, Saskatoon in association with Ottawa-based colleagues, H.A. Senn and H. Groh, (2937, in DAO, SASK \& RCR). Two early collections are present in herbaria with locality designations given only as "Prince Albert": one by O.C. Furniss on 17 July 1949 in "muskeg", (S2999(a), in SASK, DAO, \& RCR), and the other by George F. Ledingham on 29 July 1950 in "wet 


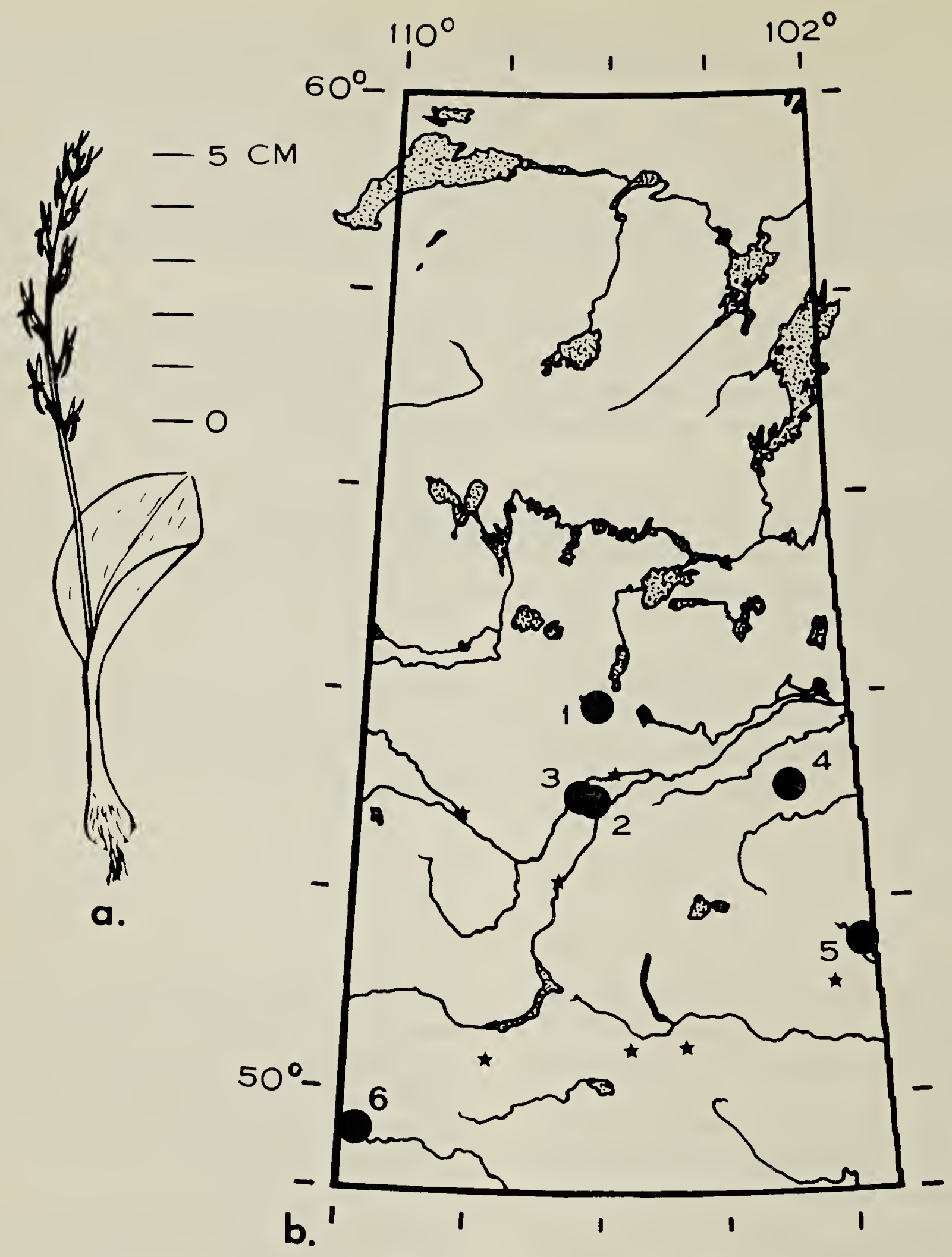

Figure 1. The White Adder's-mouth a) Plant habit sketch b) Map of known Saskatchewan distribution.

spruce woods" (975, in USAS). Apparently both are still attributable to the previous Macdowall site (in the general Prince Alberta district), and do not represent a separate "Prince Albert" locality as was implied by the text and map in Maher, et al. ${ }^{17}$ Subsequent collections from the Macdowall locality (all within a 2-mile radius) were made by George F. Ledingham and John $\mathrm{H}$. Hudson 12 July 1952 "from boggy mossy spruce woods, in only the shadiest places" (1020 \& 1487, in SASK, USAS, JHH, etc.), and by John and Heather Hudson 2 August 1981 from a "moist peaty Carex sward ... at 
edge of marsh" (4171, in SASK, JHH, etc.). John Hudson also collected this orchid from near Garthland, about 16 miles northwest of the Macdowall station, 14 September 1974 from "wet black spruce woods" (3040, in SASK \& $\mathrm{JHH}) .{ }^{14}{ }^{15}$ Although all locality citations were omitted in Edition 3 of the Fraser and Russell provincial plant list, the Macdowall locality ws quite obviously known to the revisors, since two of them, R.C. Russell and G.F. Ledingham, had already collected it from there, and as revealed by the fact that soil zones 3 and 4 , as well as 5 , were indicated for the species. ${ }^{10}$

The fourth and fifth Saskatchewan localities (actually third and fourth general localities because of the proximity of the Macdowall and Garthland sites) to be recorded for White Adder'smouth were the previously mentioned significant finds by Bernard de Vries 26 June 1972 from Little Boggy Creek northeast of Runnymede (4466.72, in FQH), and by Donald Hooper 9 August 1982 from the edge of a spring-pond in the Fir River Valley of the Pasquia Hills in SASK) ${ }^{5613}$

Recently a sixth and very significant Saskatchewan locality has been added for this orchid, based on a collection by George F. Ledingham and Gwen J. Jones, 20 July 1983, from the Cypress Hills west block, west of the University of Regina Field Station, growing in "white spruce wet woods ... (on) northfacing slopes near seepage areas" (8084, in USAS \& SASK).

From the specimen label data, the habitat of the White Adder's-mouth Orchid in Saskatchewan would appear to be moist to wet black spruce-larch boggy woods and treed bogs, or wet peaty sedge-fens. See figure 1 for a habit sketch and map of the verified Saskatchewan distribution of this species.

Bog Adder's-mouth, Malaxis palu- dosa (L.) Swartz, appears even rarer in Saskatchewan than the previous species. It has been infrequently encountered and collected, and is scarcer wherever coexistent. August J. Breitung apparently made the first Saskatchewan collection of this species 30 July 1939 from a "sphagnum swamp" seven miles east of McKague (314, in DAO). The specimen label bears the added rarity notation "only 1 plant found there". Unfortunately, the specimen was misidentified as Northern Bog Twayblade (Liparis loeselii (L.) Rich.), so Bog Adder's-mouth was never included in either of his catalogues. ${ }^{34}$ Boivin, who in 1965 had correctly annotated Breitung's specimen from the McKague area, included Saskatchewan within the range he gave for Bog Adder's-mouth, although without locality information, presumably on the basis of this collection. ${ }^{1}$ The first Saskatchewan report of this species with locality information was by Hudson, based upon his 1976 collection from near Garthland 14 September 1974 in "wet springy black spruce woods", represented by a single plant intermixed with a collection of White Adder's-mouth $(3039, \mathrm{JHH}) .^{14}$ Similarly, in 1978, I determined and annotated as Bog Adder's-mouth a single plant on a sheet of White Adder's-mouth collected from "moist black spruce woods" $7 \mathrm{mi}$. south of Macdowall (Ledingham \& Hudson, 1487, USAS). The latter was the basis of the Macdowall record in the Syllogeus list of Saskatchewan rare plants. ${ }^{17}$

Subsequently, Bernard de Vries has reported two significant records of Bog Adder's-mouth, one collected 26 June 1974 from a bog "in coniferous woods" at Nipawin (de Vries, 3027.74, FQH) ${ }^{5}$, and the other 27 June 1982 from the "gravelly shores of Madge Lake among young spruce" in Duck Mountain Provincial Park (de Vries, 7315.82,FQH). ${ }^{56}$ 


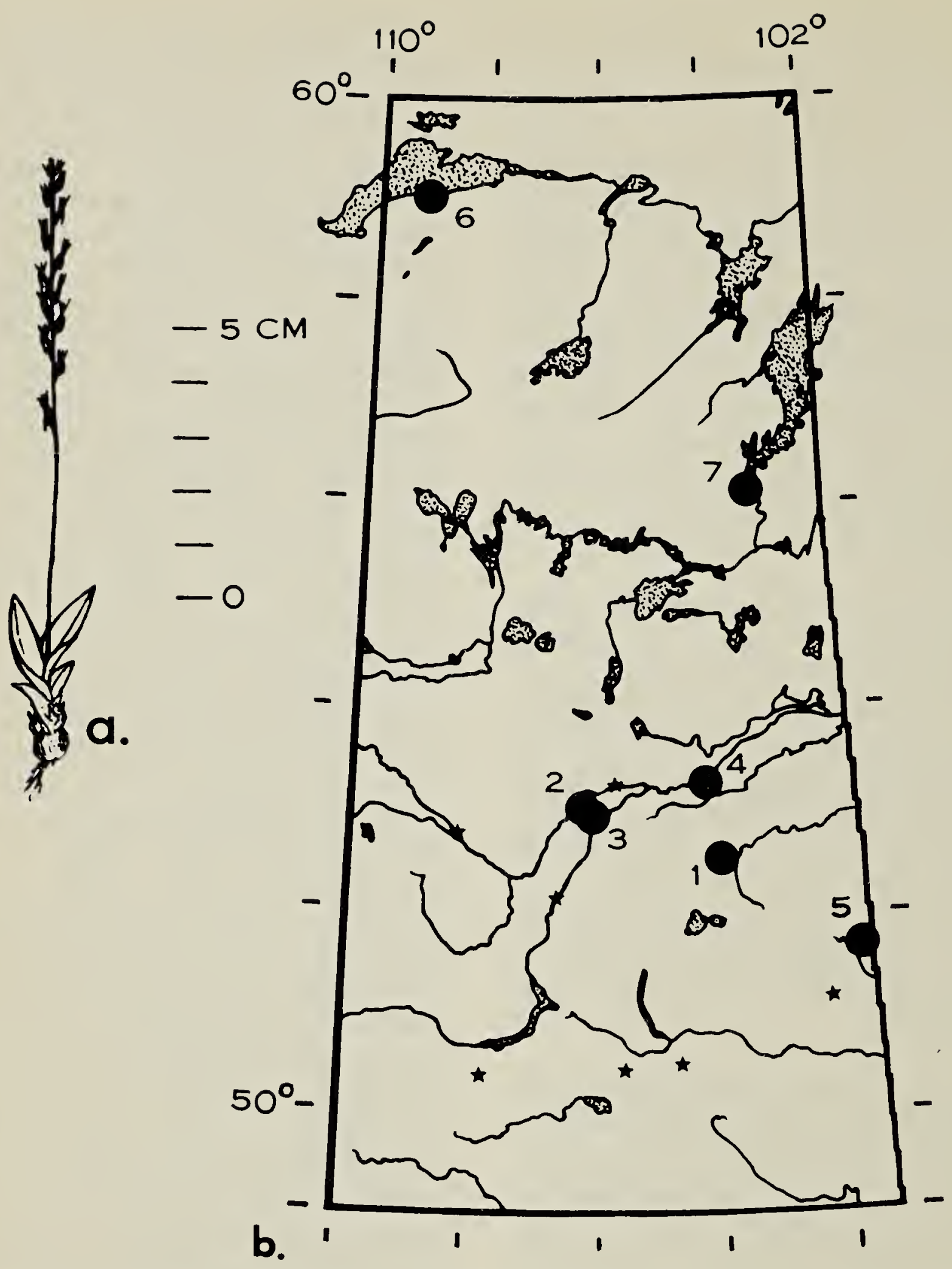

Figure 2. The Bog Adder's-mouth a) Plant habit sketch b) Map of known Saskatchewan distribution.

Two other reports of Bog Adder'smouth from northern Saskatchewan represent significant records for the province. The first is a collection 6 July 1979 from Cantara Bay (about $5 \mathrm{~km}$ southeast of Beaver Point) on the south shore of Lake Athabasca, in moist springy woods (Harms, Hudson \&
Wright, 24970, SASK). ${ }^{12}$ The second is a collection by John Hudson 6 August 1982 from a floating bog at the mouth of Little Deer River near Southend $\left(\mathrm{JHH}, 4258\right.$, SASK, USAS \& JHH). ${ }^{16}$ Interestingly, the latter appears to be the only Saskatchewan locality where individuals of this species, while hardly 
frequent, at least were not extremely scarce. John Hudson (pers. comm.) also reports a sight record (uncollected) of one plant from a large bog along Hwy. 105, about $20 \mathrm{~km}$ west of Southend, $13 \mathrm{~km}$ north of the junction with Hwy. 102.

From the available specimen label information, the habitat in Saskatchewan of Bog Adder's-mouth appears similar to that of White Adder's-mouth - viz. moist black spruce woods, bogs, sedgefen borders, and moist wooded or semi-wooded shores. It appears to have a more northerly range in the province. See figure 2 for a habit sketch and map of the verified Saskatchewan distribution of this species.

Although early Saskatchewan reports are unverified, a third species, the true Green Adder's-mouth, $M$. unifolia Michx., could possibly be discovered in this province. ${ }^{7} 89$ If Scoggan's locality report is correct of this species from near the Saskatchewan River mouth north of Lake Winnipegosis, Manitoba (reportedly based upon a collection by John Macoun in CAN), it should be looked for in nearby east-central Saskatchewan. ${ }^{18}$ In the Syllogeus list of Manitoba rare plants White and Johnson, however, omitted the latter locality for the species; their compilation shows this orchid still unverified west of the Sandilands Forest Reserve in southeastern Manitoba, and thus very unlikely for Saskatchewan. ${ }^{19}$ Boivin, (by his parenthetical inclusion) implied that all Manitoba reports of Green Adder's-mouth need vertification, or at least that he had not seen any from that province. ${ }^{2}$

'BOIVIN, B. 1967. Enumeration des Plantes du Canada, V - Monopsides (l'ere partie), Naturaliste Can. 94:131-157 ( $p$. 149).

${ }^{2}$ BOIVIN, B. 1979. Flora of the Prairie Provinces, Part IV - Monopsida.
Provancheria 5, Mem. de l'Herbier Louis Marie, Univ. Laval. 189 pp. (p. 39).

${ }^{3}$ BREITUNG, A.J. 1947. Catalogue of the Vascular Plants of Central Eastern Saskatchewan. The Canadian FieldNaturalist 61:71-100 (p. 82).

${ }^{4}$ BREITUNG, A.J. 1957. Annotated catalogue of the vascular flora of Saskatchewan. American Midland Naturalist 58:1-72 (p. 22).

${ }^{5}$ de VRIES, B. 1983. Personal Communication - "Orchid Specimens in FQH", 18 May 1983.

${ }^{6}$ de VRIES, B. 1983. White Adder's-mouth and other unusual plants. Blue Jay 41(3):140.

'FERNALD, M.L. 1950. Gray's Manual, 8th Ed. American Book Co., New York. 1632 pp. (p. 485).

${ }^{8}$ FRASER, W.P., and R.C. RUSSELL. 1937. List of the Flowering Plants, Ferns and Fern Allies of Saskatchewan. University of Saskatchewan, Saskatoon.

${ }^{9}$ FRASER, W.P., and R.C. RUSSELL. 1944. A Revised, Annotated List of the Plants of Saskatchewan. University of Saskatchewan, Saskatoon.

${ }^{10}$ FRASER, W.P., and R.C. RUSSELL (Revised by R.C. Russell, G.F. Ledingham \& R.T. Coupland). 1953. An Annotated List of the Plants of Saskatchewan. University of Saskatchewan Saskatoon.

"HARMS, V.L. 1978. A tentative checklist of the rare and potentially endangered native vascular plants of Saskatchewan. The W.P. Fraser Herbarium, University of Saskatchewan. 32 pp. (p. 20).

${ }^{12}$ HARMS, V.L. Additions to the Vascular Plant Flora of the Lake Athabasca South Shore. Canadian Field-Naturalist. (In press).

${ }^{13}$ HOOPER, D.F. 1983. A new Saskatchewan record for Adder's-mouth. Blue Jay 41(1):9-10. 
${ }^{14}$ HUDSON, J.H. 1976. 1974 plant records from Saskatchewan, rediscoveries, discoveries and other curiosities. Blue Jay 34(1):9-13.

${ }^{15}$ HUDSON, J.H. 1977. Rare and endangered native plants in Saskatchewan south of Lat. $55^{\circ}$. Blue Jay $35(3): 126-137$

${ }^{16} \mathrm{HUDSON}$, J.H. A second Evening Star in Saskatchewan - Blue Jay 42(1):2021.

${ }^{17}$ MAHER, R.V., G.W. ARGUS, V.L. HARMS, and J.H. HUDSON. 1979. The Rare
Vascular Plants of Saskatchewan. Syllogeus No. 20, National Museum of Natural Sciences. Ottawa, Ontario. 55 pp. + maps (p. 33).

18SCOGGAN, H.J. 1978. Flora of Canada, Park 2. Pteridophyta, Gymnospermae, Monocotyledoneae. National Museums of Canada, Ottawa. 1711 pp. (p. 542).

${ }^{19}$ WHITE, D.J., and K.L. JOHNSON. 1980. The Rare Vascular Plants of Manitoba. Syllogeus No. 27. National Museum of Natural Sciences, Ottawa, Ontario. 52 pp. + maps (p. 29).

\section{A SECOND EVENING STAR IN SASKATCHEWAN}

JOHN H. HUDSON, 103 Richmond Crescent, Saskatoon, Saskatchewan. S7N 1 A9

In June 1982 I had the opportunity to go along on a field trip to Val Marie set up as a post-convention tour by the Canadian Botanical Association. One of the stops was 70-Mile Butte, on the north side of the Frenchman, some five miles down-river from Val Marie (but of course longer by trail). The group was wandering over a steep south-facing slope of bentonitic clay when George Ledingham and Gordon Thomas from the Regina Research Station came up to me with a plant for identification. While I was puzzling over it, for I had never seen it before, I was told by George that Mr. Thomas had offered to bet him $\$ 25.00$ that I didn't know it, and George had a good mind to take him up on this bet. I said, "You would have lost, for I don't know it - never saw it before. However, l'd tentatively guess Loasaceae, because of the extreme roughness of the leaves".

You may be sure I, too, collected some material and when I got home it proved to be a Mentzelia albicaulis Dougl., known in Canada hitherto only in the dry interior of British Columbia. Collection data are as follows: "Hudson 4208, Val Marie, SeventyMile Butte, LSD 15 in 11-3-XIII W. 3rd. Dry south-facing annual-inhabited coulee slope, soil loose chunky bentonitic clay, lying at angle of repose".

The general appearance of the plant is not a bit like its larger relative 